\title{
Health Risk Assessment and Levels of Heavy Metals in Farmed Nile Tilapia (Oreochromis niloticus) from the Volta Basin of Ghana
}

\author{
Emmanuel Kaboja Magna ${ }^{(D)},{ }^{1}$ Samuel Senyo Koranteng, ${ }^{2}$ Augustine Donkor, ${ }^{3}$ \\ and Christopher Gordon ${ }^{2}$ \\ ${ }^{1}$ CSIR-Water Research Institute, Accra, Ghana \\ ${ }^{2}$ Institute for Environment \& Sanitation Studies, University of Ghana, Legon-Accra, Ghana \\ ${ }^{3}$ Department of Chemistry, University of Ghana, Legon-Accra, Ghana \\ Correspondence should be addressed to Emmanuel Kaboja Magna; egmagna@yahoo.co.uk
}

Received 8 September 2021; Revised 30 November 2021; Accepted 20 December 2021; Published 31 December 2021

Academic Editor: Shafaqat Ali

Copyright (c) 2021 Emmanuel Kaboja Magna et al. This is an open access article distributed under the Creative Commons Attribution License, which permits unrestricted use, distribution, and reproduction in any medium, provided the original work is properly cited.

\begin{abstract}
Heavy metals ( $\mathrm{Pb}, \mathrm{Cd}, \mathrm{As}, \mathrm{Mn}, \mathrm{Fe}, \mathrm{Zn}, \mathrm{Cu}, \mathrm{Ni}$, and $\mathrm{Cr}$ ) are some of the most toxic elements that can bioaccumulate from sources linked to human activities, such as industry and agriculture. This study quantifies the concentrations of several heavy metals in caged tilapia found in Ghana's Volta Basin and assesses the associated health risks. The levels of heavy metals in the tissues of Oreochromis niloticus from three cage farms $(N=52)$ were determined using Atomic Absorption Spectrometry (AAS). The implication for human health was assessed using several risk assessment techniques. Fe $(50.11 \pm 10.22 \mathrm{mg} / \mathrm{kg})$ and $\mathrm{Cr}$ $(0.31 \pm 0.07 \mathrm{mg} / \mathrm{kg})$ had the highest and lowest accumulated metal concentrations, respectively. Heavy metal concentrations in tilapia tissue from fish farms were ordered as follows: $\mathrm{Fe}>\mathrm{Mn}>\mathrm{Zn}>\mathrm{Ni}>\mathrm{Cr}$ (farm A), $\mathrm{Fe}>\mathrm{Zn}>\mathrm{Ni}>\mathrm{Mn}$ (farm B), and $\mathrm{Fe}>\mathrm{Mn}>\mathrm{Zn}>\mathrm{Ni}>\mathrm{Cr}$ (farm C). All metals had an estimated daily intake (EDI) below the threshold, and mean differences between sample farms were not statistically significant. Similarly, the values of target hazard quotients (HQs) and hazard indices (HIs) were less than one. According to the risk assessment results, eating tilapia from farms posed no risk to human health. The presence of $\mathrm{Mn}, \mathrm{Fe}$, and $\mathrm{Ni}$ concentrations above the maximum level in the fish, on the other hand, suggests that they may affect fish health.
\end{abstract}

\section{Introduction}

Global fish consumption has increased in recent years, owing to the growing awareness of fish's nutritional and therapeutic benefits. Fish is low in cholesterol and contains all essential amino acids and is estimated to provide roughly $60 \%$ of the world's protein requirements, with $60 \%$ of the developing world obtaining more than $30 \%$ of their animal protein from fish [1]. In addition to being a good source of protein, fish is high in vitamins, unsaturated fatty acids, and essential minerals [2]. The American Heart Association recommends eating fish at least twice a week to meet the daily omega-3 fatty acid requirement [3]. Regrettably, some forms of human activity have posed a significant threat to fish habitats and aquatic ecology in recent years $[1,4,5]$. Due to the rapid population growth and industrial development, increased waste discharge into aquatic ecosystems has resulted in a significant increase in metal contamination. These metals are persistent and nonbiodegradable in the ecosystem, which results in metal bioaccumulation in aquatic biota, including fish [6].

Heavy metals enter the aquatic food chain in two ways: directly through the gastrointestinal tract when food and water are consumed and indirectly through nondietary pathways, such as gills and muscles [2]. As a result, the concentrations of heavy metals found in fish tend to correlate with those found in the water and sediment of the aquatic habitat from which they are drawn, as well as the duration of exposure [7]. Nonessential metals such as lead, cadmium, arsenic, and mercury are considered highly toxic, 
even in trace amounts. There are histopathological and physiological consequences when an organism's metabolic, storage, and detoxifying processes cannot balance absorption [8]. Apart from being persistent and toxic, nonessential metals are bioaccumulated and metabolically regulated via various mechanisms, including active excretion and storage [9]. Heavy metals can build up in fish and proliferate throughout the food web, causing health problems in humans, such as cardiovascular, renal, and neurological disorders [10, 11]. Environmental pollution and fish vulnerability to heavy metal contaminants are primarily due to exposure to anthropogenic sources, such as agricultural and domestic pesticides, fertilisers, incinerator emissions, municipal or local waste emissions, and smelting and mining operations [12].

The demand for seafood products increases as the world's population grows at an accelerating pace in the twenty-first century [13]. Aquaculture production continues to grow year after year. Larsen and Roney [14] conducted a global analysis of animal protein consumption and discovered that in 2011, global cultured fish productivity surpassed beef production. If farmed fish are raised in metalcontaminated waters, they may accumulate metals from the sediment, water, and fish feeds, posing a greater health risk to humans who inadvertently consume a lot of fish.

Cage culture systems account for over $90 \%$ of farmed fish in Ghana, while ponds account for 10\% [15]. Cage aquaculture is the dominant commercial activity in the Volta Basin, growing at a rate of $73 \%$ per year between 2010 and 2016. Aquaculture contributes between 3\% and 5\% of the country's GDP and provides employment opportunities for the populace [16]. The vast majority of cage farmers in the Volta Basin, where this study was conducted, feed their fish with more expensive imported commercial floating feed. These feeds are fortified with anticaking agents, minerals, vitamins, and supplements, all of which can be sources of heavy metals in animal feeds [17]. The contaminated feed may transfer these nonbiodegradable heavy metals toxins to farmed fish, which humans then consume.

Additionally, the Volta Basin is under intensive and extensive farming and has some irrigation facilities for nonseasonal crop and vegetable cultivation. Farmers have applied pesticides widely and unregulated throughout the basin catchment to improve crop yield to increase profit margins. These practices release pesticides containing heavy metals into the basin during runoff, polluting the ecosystem and contaminating aquatic organisms.

Along the Volta Basin, there has been an increase in rural metal fabrication, textile factories, pottery enterprises, and livestock and poultry farms [18]. These industries are situated closer to the fish farms. Wastewater effluents from these industrial activities are released, without any treatment, into the open environment. The effluents are discharged into the basin column during runoff after rainfall, polluting the entire aquatic ecosystem. Although some of these metals discharged into the water are necessary micronutrients, their high proportion in the food web can induce toxicity and environmental effects, putting aquatic habitats and their users at risk. Few studies have been performed on heavy metals in the sediment from the caged aquaculture farms [19] in the Volta Basin. Other studies have focused on the impact of cage culture on the lake's water quality [20-22]. However, these studies have been limited to water and sediment quality in the vicinity of the cages. The heavy metals' content of the tilapia cultured in the cages has not received any attention. The research aims to determine the amounts of heavy metals in caged tilapia and estimate the potential health risks connected with the dietary ingestion of the fish.

\section{Materials and Methods}

2.1. Study Area and Sampling. The study area includes Ghana's Asuogyaman District in the eastern region and the Greater Accra region's Shai-Osudoku District. Figure 1 shows the locations of the fish farms from which samples were taken. The districts are located between $6^{\circ} 34^{\circ} \mathrm{N}$ and $6^{\circ}$ $10^{\circ} \mathrm{N}$ latitudes and $0^{\circ} 1^{\circ} \mathrm{W}$ and $0^{\circ} 14 \mathrm{E}$ longitudes. Regarding employment and rural income creation, rain-fed agriculture and irrigated agriculture are the most important economic activities in these districts. Farmers use agrochemicals extensively on their farms to increase crop productivity. As a result, the use of pesticides that are restricted or banned cannot be ruled out. The area has a two-season rainfall pattern, with the major season falling between September and November and the minor season falling between May and July.

The study used 52 cage tilapias fish (Oreochromis niloticus) purchased from three cage fish farms in the Volta Basin: $A=19, B=16$, and $C=17$. Two tilapia fish were combined into a composite working sample. The two fishes shared similar morphometric characteristics. Additionally, ten wild Oreochromis niloticus samples were collected as controls from areas upstream of the study area that does not have aquaculture. All fish samples were stored at $4^{\circ} \mathrm{C}$ in an airtight bag and transported to the Ghana Atomic Energy Laboratory for further examination.

2.2. Consideration of Ethical Issues. This study's purpose was explained to the fish farmers, who consented to their fish sampling. All scientific experiments used in the cage aquaculture tilapia (Oreochromis niloticus) studies were approved by the Institute for Environment and Sanitation Studies management and the University of Ghana's Research Ethical Committee.

2.3. Digestion of Fish Samples for Heavy Metals. In the laboratory, the fillets of the tilapia were removed using a stainless-steel knife. The samples were then washed with deionised water, wrapped in a precleaned aluminium foil, and stored at $-20{ }^{\circ} \mathrm{C}$ until extraction. After one week, the samples were taken out of the freezer and defrosted. The fish muscle samples were homogenised and lyophilised for 72 hours (LMC-1, Martin Christ Gefriertrocknungsanlagen $\mathrm{GmbH}$, Germany). The samples were dried in the oven at $150^{\circ} \mathrm{C}$ for 20 minutes. The samples were pounded into powder using a mortar and pestle. Then, $6 \mathrm{~mL}$ of $\mathrm{HNO}_{3}$ and 


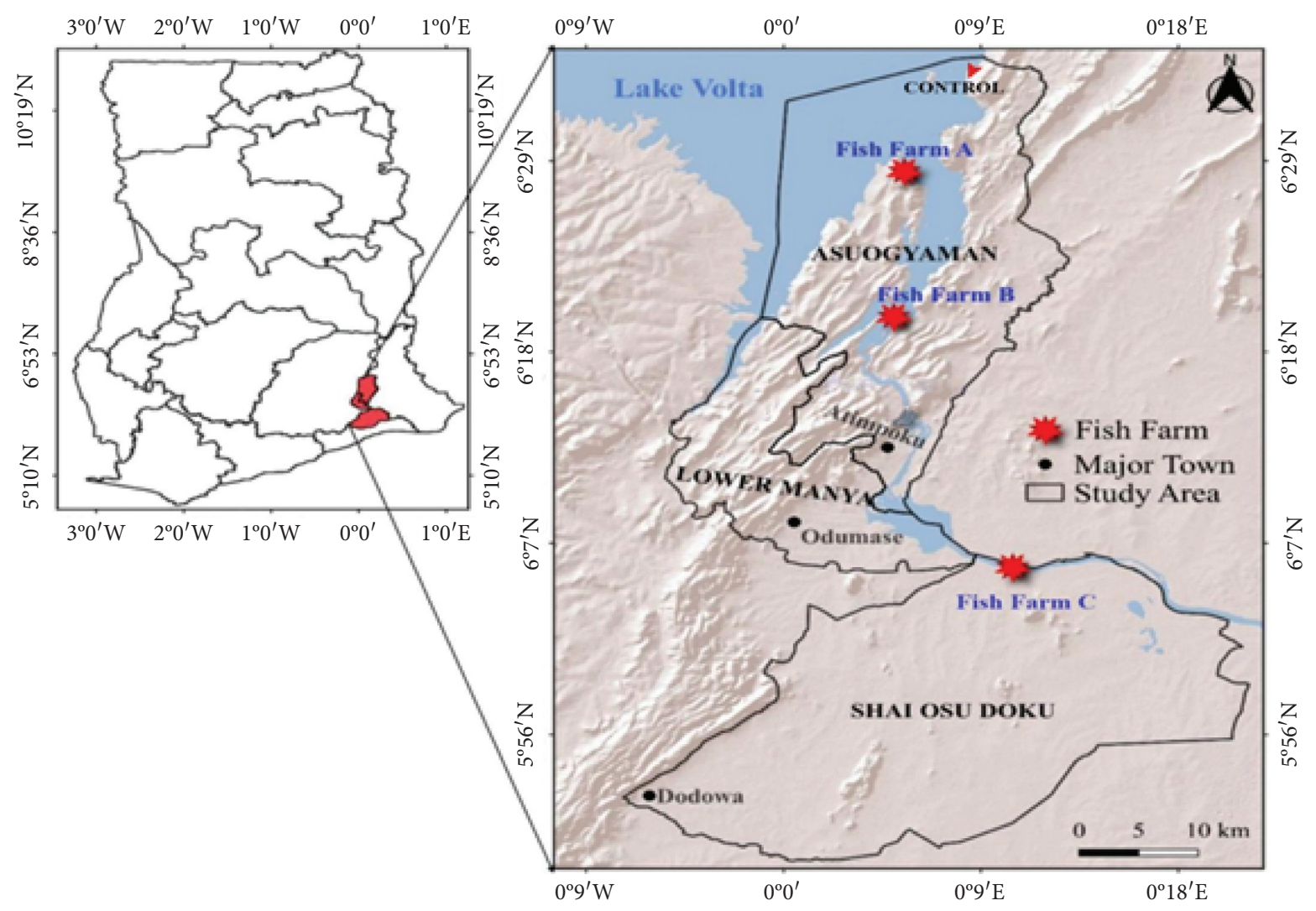

FIgURE 1: Map of the study area of the Volta Basin, Ghana.

$1 \mathrm{~mL}$ of $\mathrm{H}_{2} \mathrm{O}_{2}$ were added to $0.5 \mathrm{~g}$ of dried powdered sample in a Teflon beaker. The Teflon beakers were inserted inside the bomb and carefully capped. The bomb was situated in the centre of a microwave oven (Sineo Jupiter-A microwave) and digested at maximum power for 26 minutes. The fully digested samples were left to cool down at room temperature before being diluted with deionised water to a level of $20 \mathrm{ml}$. The Varian AA 240FS Atomic Absorption Spectrometer was used to analyse the digested samples in triplicate. The quantitative analysis included the measurement of final concentrations from the initial concentrations of the specified elements and their conversion into final concentrations using the following equation:

$$
\text { final concentration }=\frac{\text { initial conc }(\text { D.F. }) \times \text { nominal vol }}{\text { sample weight in grams }} .
$$

Nominal volume was given as $20 \mathrm{ml}$, and the sample weight for fish was $0.5 \mathrm{~g}$. Each result was expressed in $\mathrm{mg} / \mathrm{kg}$.

2.4. Quality Control and Quality Assurance (QC/QA) of the Heavy Metal Analyses. All reagents used were of analytical grade, and distilled water was also used in all the preparations. Glass materials were soaked and rinsed in $10 \%$ $\mathrm{HNO}_{3}$ for $24 \mathrm{~h}$ and distilled water, respectively. Analyses of solvent blanks, procedural matrix blanks, and samples were carried out in triplicate for quality assurance. The functioning of equipment was established using a serial dilution to verify their reliability. Precision and accuracy of procedure were verified by using standard reference materials, such as CRM 320. Recovery percentages of analytical results were within the range of $94-115 \%$ for all the metals studied.

2.5. Statistical Analysis. The Kolmogorov-Smirnov (K-S) analysis was used to determine the normality of the data, and findings were considered statistically significant when the $p$-value obtained was less than 0.05 . The levels of heavy metals in the fish muscle were described using statistics, such as means and standard deviation (SD). ANOVA was used to determine the differences in contaminants between the fish farms and controls from which samples were taken. Where statistically significant, a post hoc Tukey's HSD test was performed.

2.6. Estimation of Potential Health Risks for Human. The adverse health effects of heavy metal exposure in fish on humans were investigated using the USEPA's analytical method [23]. The risk assessment is calculated using the ingestion rate reported by [24], as shown in Table 1 .

2.6.1. Exposure Assessment. Heavy metals exposure estimations were obtained using caged tilapia (Oreochromis niloticus) as the model organism. Using USEPA-proposed methods, the concentrations of contaminants in the examined fish were employed to calculate the estimated daily 
TABLE 1: Parameters for the health risk estimations of heavy metals.

\begin{tabular}{lccc}
\hline Parameters & Units & Children & Adults \\
\hline Bodyweight (BW) & $\mathrm{kg}$ & 15 & 70 \\
Exposure frequency (EF) & Days/year & 365 & 365 \\
Exposure duration (ED) & Years & 6 & 30 \\
Ingestion rate (IR) & $\mathrm{mg} /$ day & 200 & 100 \\
Average time (AT) & & Days/year & \\
For carcinogenic & & $365 \times 70$ & $366 \times 70$ \\
For noncarcinogenic & & $365 \times \mathrm{ED}$ & $365 \times \mathrm{ED}$ \\
\hline
\end{tabular}

intake (EDI) (mg/kg/day) from ingestion of fish in this study. The equation below was used to produce separate exposure estimates for children and adults:

$$
\operatorname{EDI}\left(\mathrm{mg} / \mathrm{kg}^{-1} \mathrm{day}^{-1}\right)=\frac{(\mathrm{C} \times \mathrm{IR} \times \mathrm{EF} \times \mathrm{ED})}{(\mathrm{BW} \times \mathrm{AT})},
$$

where BW denotes body weight in kilograms and AT denotes the average exposure duration in years (life expectancy), $\mathrm{C}$ is the concentration of the examined heavy metals in the fish, $\mathrm{EF}$ is the exposure frequency (days/year), ED is the exposure duration (years), and IR is the ingestion rate of tilapia. Thus, the Estimated Daily Intakes (EDIs) for the pollutants were compared with the Reference Dose values (Rfds). The pollutant will present a relatively high risk if EDI $>$ Rfd. Using the reference dosage and Cancer Slope Factor (CSF) of various pollutants, the health risk can be estimated [23].

2.6.2. Noncarcinogenic Effects of Contaminants in Fish. The hazard quotient (HQ) is a commonly used method of risk characterisation, which is the ratio of the predicted exposure to the chemical above the level at which no detrimental effects are expected. The hazard quotient is mathematically expressed as follows:

$$
\begin{aligned}
& \mathrm{HQ}=\frac{\mathrm{EDI}}{\mathrm{Rfd}\left(\mathrm{mg} \mathrm{kg}^{-1} \mathrm{day}^{-1}\right)}, \\
& \mathrm{HQ}=\frac{C_{x I R \times E F \times E D}}{\mathrm{BW} \times \mathrm{AT} \times \mathrm{Rfd}},
\end{aligned}
$$

where IR is the ingestion rate ( $\mathrm{kg} /$ day) for normal adults ( $\geq 12$ years) and children ( $<12$ years), BW is the body weight, and $C$ is the average chemical level in fish tissues $(\mathrm{mg} / \mathrm{kg})$. The frequency of exposure (EF) (365 days/year) is the number of days per year that one is exposed to the contaminant through the consumption of contaminated fish. The exposure duration (ED) is the number of days per year that one is exposed to the contaminant through the consumption of contaminated fish (equivalent to an average of 30 years for adults and 6 for children for USEPA standard). The average lifespan of chemical exposure is denoted by AT (365/366 days $x$ ED for noncarcinogenic or carcinogenic). Hazard quotient $(\mathrm{HQ})>1$ indicates a noncarcinogenic effect on health, while $\mathrm{HQ} \leq 1$ shows no harmful influence on health. According to [24], the exposure thresholds used for health hazard calculations are shown in Table 1.

The oral Rfds of the heavy metals were as follows: As $=0.003 \mathrm{mg} / \mathrm{kg} /$ day, $\mathrm{Zn}=0.3 \mathrm{mg} / \mathrm{kg} /$ day, $\mathrm{Fe}=0.36 \mathrm{mg} / \mathrm{kg} /$ day, $\quad \mathrm{Ni}=0.2 \mathrm{mg} / \mathrm{kg} /$ day, $\quad \mathrm{Pb}=0.000035 \mathrm{mg} / \mathrm{kg} / \mathrm{day}$, $\mathrm{Cr}=0.003 \mathrm{mg} / \mathrm{kg} / \mathrm{day}$, and $\mathrm{Mn}=0.014 \mathrm{mg} / \mathrm{kg} / \mathrm{day}[25,26]$.

The Hazard Index (HI) adapted from [27] is the cumulative toxicity risk of metals on human health. It was obtained to measure the noncarcinogenic threats to humans using the relation in the following equation:

$$
\mathrm{HI}=\sum_{i=1}^{n} \mathrm{HQ}_{i},
$$

where $\mathrm{HQ}_{i}$ represents the hazard quotient for the $i$ th metal. Hazard Index $(\mathrm{HI})>1$ indicates a noncarcinogenic effect on health, while $\mathrm{HI} \leq 1$ shows no harmful effect.

2.6.3. Carcinogenic Risk Assessment. Individuals may be exposed to cancer through the consumption of fish contaminated with pollutants. To examine this, a carcinogenic risk evaluation, which predicts the likelihood of a person developing cancer over a lifespan, resulting from exposure to possible carcinogens [27], was estimated. The main assessment parameter, called the cancer slope factor (CSF), was obtained from the USEPA carcinogenic risk assessment. The CSF represents the probable upper-bound estimate of the likelihood that a person will develop cancer if exposed to a chemical (cancer-causing agent) for a lifetime of 70 years. Therefore, the target risk of cancer was estimated using the following equation:

$$
\mathrm{TCR}=\mathrm{EDI} \times \mathrm{CSF},
$$

where CSF is the cancer slope factor of the individual pollutant and TCR is the target cancer risk. The CSF values used for the carcinogenic estimation for the heavy metals $\mathrm{Ni}$, $\mathrm{As}, \mathrm{Pb}, \mathrm{Cr}$, and $\mathrm{Cd}$ were as follows: $\mathrm{Ni}=0.91 \mathrm{mg} / \mathrm{kg} / \mathrm{day}$, $\mathrm{Cd}=0.38 \mathrm{mg} / \mathrm{kg} /$ day, $\mathrm{Pb}=0.0085 \mathrm{mg} / \mathrm{kg} /$ day,$\quad \mathrm{Cr}=0.5 \mathrm{mg} /$ $\mathrm{kg} /$ day, and As $=1.5 \mathrm{mg} / \mathrm{kg} /$ day $[28,29]$.

\section{Result and Discussion}

Six heavy metals ( $\mathrm{Zn}, \mathrm{Fe}, \mathrm{Mn}, \mathrm{Ni}, \mathrm{As}$, and $\mathrm{Cr}$ ) were detected in the muscle tissues of tilapia at a $100 \%$ frequency of occurrence. Table 2 summarises the findings. Other heavy metals such as copper, cadmium, and lead were below the detection limit. The concentrations of heavy metals at the various sampling points did not differ significantly $(p<0.05)$. The mean concentration of heavy metals ranged from $0.31 \mathrm{mg} / \mathrm{kg}$ to $50.11 \mathrm{mg} / \mathrm{kg}$. Fe concentrations of up to $50 \mathrm{mg} / \mathrm{kg}$ were detected in the muscle tissues of tilapia at fish farm B (Table 2). In contrast, $\mathrm{Cr}$ concentrations were the lowest in tilapia from fish farm A. Only the control samples contained arsenic. Heavy metal concentrations in tilapia tissue from fish farms were classified as follows: $\mathrm{Fe}>\mathrm{Mn}>\mathrm{Zn}>\mathrm{Ni}>\mathrm{Cr}$ (for fish farm A), $\mathrm{Fe}>\mathrm{Zn}>\mathrm{Ni}>\mathrm{Mn}$ (for fish farm B), and $\mathrm{Fe}>\mathrm{Mn}>\mathrm{Zn}>\mathrm{Ni}>\mathrm{Cr}$ (for fish farm C). Ni, Mn, and Fe had concentrations in the muscles of O. niloticus exceeding the USEPA/WHO legal limit for human consumption, implying that fish from the farms could potentially cause $\mathrm{Ni}-$, $\mathrm{Fe}-$, and $\mathrm{Mn}$-related health problems over time. 
TABLE 2: Levels of heavy metals concentrations $(\mathrm{mg} / \mathrm{kg})$ in caged tilapia from fish farms.

\begin{tabular}{|c|c|c|c|c|c|c|c|c|}
\hline \multirow[b]{2}{*}{ Metals } & \multicolumn{2}{|c|}{ Fish farm A } & \multicolumn{2}{|c|}{ Fish farm B } & \multicolumn{2}{|c|}{ Fish farm C } & \multicolumn{2}{|c|}{ Controls } \\
\hline & Mean \pm SD & Range & Mean \pm SD & Range & Mean \pm SD & Range & Mean \pm SD & Range \\
\hline $\mathrm{Zn}$ & $2.07 \pm 0.140$ & $1.80-2.28$ & $2.13 \pm 0.33$ & $1.92-2.80$ & $1.82 \pm 0.29$ & $1.80-2.28$ & $0.97 \pm 0.20$ & $0.58-1.11$ \\
\hline $\mathrm{Fe}$ & 37. $28 \pm 10.84$ & $21.60-54.80$ & $50.11 \pm 10.22$ & $38.92-62.6$ & $39.58 \pm 9.14$ & $21.6-54.80$ & $11.09 \pm 2.03$ & $8.21-14.21$ \\
\hline $\mathrm{Mn}$ & $3.41 \pm 2.03$ & $1.64-8.80$ & $1.76 \pm 0.69$ & $1.04-3.08$ & $2.46 \pm 0.60$ & $1.64-8.80$ & $0.77 \pm 0.15$ & $0.52-0.96$ \\
\hline $\mathrm{Ni}$ & $1.62 \pm 0.03$ & $1.58-1.64$ & $2.74 \pm 1.87$ & $0.03-5.04$ & $2.00 \pm 0.14$ & $1.58-1.64$ & $0.65 \pm 0.11$ & $0.52-0.81$ \\
\hline $\mathrm{Cr}$ & $0.31 \pm 0.07$ & $0.20-4.00$ & - & - & $0.33 \pm 0.07$ & $0.20-0.40$ & $0.10 \pm 0.02$ & $0.07-0.12$ \\
\hline As & - & - & - & - & - & - & $0.23 \pm 0.07$ & $0.15-0.32$ \\
\hline
\end{tabular}

A small amount of $\mathrm{Mn}$ is required for normal human development and growth. The US EPA has established an Rfd of $140 \mathrm{~g} / \mathrm{kg} /$ day for Mn, which becomes harmful when consumed above this level [30]. The lowest and highest $\mathrm{Mn}$ concentrations were found in Oreochromis niloticus from the wild and farm A, respectively, at $0.77 \mathrm{mg} / \mathrm{kg}$ and $3.41 \mathrm{mg} / \mathrm{kg}$. Aquatic organisms are known to absorb pollutants from the water and store them at much higher concentrations than the rest of their ecosystem; thus, elevated heavy metal concentrations in aquatic organisms' tissues suggest cumulative exposure to Mn-contaminated water [31]. For this study, there were elevated levels of $\mathrm{Mn}$ in the analysed fish feed than the maximum residue levels required in the fish diet by FAO (see Table 3). There was also a significant positive correlation of Fe-Mn $(r=0.852, p<0.01)$ and $\mathrm{Mn}$ Mn $(r=0.852, p<0.01)$ in fish and fish feed as in Table 4, indicating that the high level of manganese in the caged fish was probably due to the uptake from the fish feed. In this study, the Mn content of tilapia muscle tissues ranged between 0.77 and $3.41 \mathrm{mg} / \mathrm{kg}$ (ww). In literature, $0.49-0.84 \mathrm{mg} /$ $\mathrm{kg}$ manganese concentrations in O. niloticus from Burullus Lake, Egypt, was reported [32], 0.05-4.64 mg/kg dry weight in commercially valuable fish species from Iskenderun Bay, North East Mediterranean Sea, Turkey [33], and $0.22-1.84 \mathrm{mg} / \mathrm{kg}$ in freshwater fish from central and eastern Norway has also been reported [34]. Additionally, Mn concentrations in muscle tissue of fish from the Mediterranean and Marmara Seas, Black Sea, and Aegean Sea varied between $0.07-3.62 \mathrm{mg} / \mathrm{kg}(\mathrm{ww})$ and $0.03-1.72 \mathrm{mg} / \mathrm{kg}(\mathrm{ww})$, respectively [35]. For this study, the Mn content of muscle tissues was within the range previously reported [35] but was lower than the $21.1-33.0 \mathrm{mg} / \mathrm{kg}(\mathrm{ww})$ found in Egyptian fish species by [36]. According to WHO standards, the maximum allowable concentration of $\mathrm{Mn}$ is $1.00 \mathrm{mg} / \mathrm{kg}$ [37]. $\mathrm{Mn}$ contents in tilapia muscles tissues from the farms were far beyond the WHO threshold.

Fe is a necessary element for the proper functioning of cells in organisms. Consumption of iron above $700 \mathrm{~g} / \mathrm{kg} / \mathrm{day}$ has been linked to type 2 diabetes and Alzheimer's disease [35]. The lowest and highest Fe concentrations were observed in Oreochromis niloticus from the wild and farm B, respectively, at $11.09 \mathrm{mg} / \mathrm{kg}$ and $50.11 \mathrm{mg} / \mathrm{kg}$. The levels of Fe in the studied tilapia were far higher than the controls. In addition, the analysed fish feeds in the fish farms, mainly from farms $\mathrm{A}$ and $\mathrm{C}$, showed higher levels of Fe beyond the WHO/FAO levels (see Table 3). The Pearson correlation matrix for heavy metal concentrations in fish and fish feed revealed significant correlations between $\mathrm{Fe}-\mathrm{Fe}(r=0.958$, $p<0.01)$ and Fe-Mn $(r=0.852, p<0.01)$ in fish feed and tilapia muscles as in Table 2, indicating their similar origins or comparable chemical properties [38]. In line with these, the elevated Fe levels in the farmed fish may be due to the uptake of iron-fortified fish feed during the investigation period. The mean Fe concentrations in this study ranged between 11.09 and $50.11 \mathrm{mg} / \mathrm{kg}$ (ww). Fe levels in the study were within the range $5.15-135.00 \mathrm{mg} / \mathrm{kg}$ (ww) for fishes from the Turkish Sea [39] but were greater than $0.21-3.59 \mathrm{mg} / \mathrm{kg}$ for fishes from the Mediterranean Sea [40]. The highest concentration of Fe was detected in the flesh of tilapia in Egypt's El-Fayoum Province, ranging from 63.6 to $120 \mathrm{mg} / \mathrm{kg}$ [36]. El-Batrawy et al. [32] reported Fe concentrations in Burullus Lake fish ranging from 8.42 to $13.18 \mathrm{mg} / \mathrm{kg}$ wet weight. Both of these studies found concentrations higher than those obtained in the current study.

Chromium is a critical trace metal required for the biologically useful state of glucose metabolism [41]. Farm C $(0.33 \pm 0.07 \mathrm{mg} / \mathrm{kg}$ ) had the highest $\mathrm{Cr}$ content (average value) in the consumable portion (tilapia flesh), while farm A $(0.31 \pm 0.07 \mathrm{mg} / \mathrm{kg})$ had the lowest. There was no significant correlation between the levels of $\mathrm{Cr}$ in fish and that of the fish feed (see Table 4). Therefore, the sources of $\mathrm{Cr}$ in the tilapia could not be attributed to the fish feed. However, the pottery, clothing, and dyeing factories activities along the Volta Basin likely explain the elevated $\mathrm{Cr}$ concentrations in the fish's muscles studied from farms $\mathrm{A}$ and $\mathrm{C}$. This local factory uses chromium salts in its dyeing operations [42]. As a result, the Volta Basin may become severely chromium polluted without proper and efficient waste management.

The Cr concentration $(0.07-4.00 \mathrm{mg} / \mathrm{kg})$ in this study matched the range observed by [33] in fish species from Iskenderun Bay. Taweel et al. [43] determined that O. niloticus farmed in Malaysia had $\mathrm{Cr}$ concentrations of $5.70-6.21 \mathrm{mg} / \mathrm{kg}(\mathrm{ww})$, and [44] determined that T. nilotica cultivated in Chittagong, Bangladesh's south-eastern region, had $\mathrm{Cr}$ concentrations of $0.590 \pm 0.052 \mathrm{mg} / \mathrm{kg}$. Both investigations found slightly higher $\mathrm{Cr}$ concentrations than this study. Hasan et al. [45] determined a Cr concentration of $0.75 \pm 0.02 \mathrm{mg} / \mathrm{kg}$ (ww) in market fish from Dhaka, [46] determined a Cr concentration of $0.524 \pm 0.053 \mathrm{mg} / \mathrm{kg}$ (ww) in cultured fish Pangasianodon hypothalamus in India, and [47] determined a Cr concentration of $0.54-2.46 \mathrm{mg} / \mathrm{kg}$ in cultured tilapia on Taiwan's southwest coast. Cr levels in all of these regions exceeded those found in our study. On the other hand, the present study $\mathrm{Cr}$ concentrations were higher than the $0.15 \mathrm{mg} / \mathrm{kg}$ observed by [48] in farmed grass carp in the Pearl River, China. Except for farm B and controls, mean 
TABLE 3: Levels of heavy metals concentrations $(\mathrm{mg} / \mathrm{kg})$ in the fish feed from fish farms.

\begin{tabular}{lcccc}
\hline Heavy metals & Fish farm A & Fish farm B & Fish farm C & $\begin{array}{c}\text { FAO } \\
\text { /EU MRL }\end{array}$ \\
\hline $\mathrm{Fe}$ & 109.20 & 96.14 & 115.42 & 100.00 \\
$\mathrm{Ni}$ & 0.76 & 0.22 & - & 8.00 \\
$\mathrm{Mn}$ & 11.40 & 11.60 & 11.90 & 7.70 \\
$\mathrm{Zn}$ & 0.26 & 0.43 & 0.23 & 150.00 \\
$\mathrm{Cr}$ & - & - & 0.44 & 1.00 \\
\hline
\end{tabular}

Cr levels in tilapia fish species were less than the [49] standard limit of $12-13 \mathrm{mg} / \mathrm{kg}$, but all fish on farms A and C exceeded the FAO [50] approved threshold of $0.15 \mathrm{mg} / \mathrm{kg}$. When $\mathrm{Cr}$ is consumed, it plays a critical role in glucose and lipid metabolism. Cr deficiency can impede progress and result in protein, glucose, and lipid metabolism [50]. However, excessive $\mathrm{Cr}$ consumption can result in acute respiratory diseases [10] and damage the lungs, liver, and kidneys [51]. When $\mathrm{Cr}(\mathrm{III})$ is present in high concentrations in body cells, it has the potential to destroy DNA [44].

$\mathrm{Zn}$ is required for the proper functioning of the human metabolic pathways, and thus its deficiency may result in loss of appetite, stunted growth, skin changes, and immune system dysfunction [52]. Additionally, zinc is required for cell division, normal protein synthesis, the immune system, and collagen formation [53]. On the other hand, a higher concentration of $\mathrm{Zn}$ becomes harmful to human health [54]. Among the $O$. niloticus under investigation, the highest concentration of $\mathrm{Zn}$ was found in fish from farm $\mathrm{B}$. $\mathrm{Zn}$ concentrations in the farmed fish followed the following order: farm B $(2.13 \pm 0.330 \mathrm{mg} / \mathrm{kg}$ wet weight $)>$ farm A $(2.07 \pm 0.140 \mathrm{mg} / \mathrm{kg}$ wet weight $)>$ farm C $(1.82 \pm 0.29 \mathrm{mg} / \mathrm{kg}$ wet weight $)>$ controls $(0.97 \pm 0.20 \mathrm{mg} / \mathrm{kg}$ wet weight $)$, which were significantly less than the FAO and WHO permissible limits for $\mathrm{Zn}$ in fish of $30 \mathrm{mg} / \mathrm{kg}$ and $40 \mathrm{mg} / \mathrm{kg}$, respectively [55]. The $\mathrm{Zn}$ metal concentrations in the studied tilapia from fish farms were below the permissible limit for human consumption established by studies in some countries, for example, England (i.e., $50 \mathrm{mg} / \mathrm{kg}$ ) [55]; El-Fayoum Province, Egypt $\quad(49.2-66.3 \mathrm{mg} / \mathrm{kg}) \quad[36]$; and Bangladesh (16.25-0.303 mg/kg) [36]. Others are Taiwan (9.06-26.2 mg/ $\mathrm{kg})$ for tilapia [47]; China's Pearl River Delta $(25.2 \mathrm{mg} / \mathrm{kg})$ for farmed grass carp [48]; and Malaysia $(29-45 \mathrm{mg} / \mathrm{kg}$ ) for O. niloticus [43]. Such elevated Zn levels may result from contamination in the aquatic environment in which the fish are raised.

Humans obtain nickel primarily through natural food sources and food production. The mean Ni concentrations in the O. niloticus concentrations in farms $\mathrm{A}, \mathrm{B}, \mathrm{C}$, and controls were $\quad 1.62 \pm 0.03 \mathrm{mg} / \mathrm{kg}, \quad 2.74 \pm 1.87 \mathrm{mg} / \mathrm{kg}$, $2.00 \pm 0.14 \mathrm{mg} / \mathrm{kg}$, and $0.65 \pm 0.11 \mathrm{mg} / \mathrm{kg}$, respectively. $\mathrm{Ni}$ concentrations in the entire sampled $O$. niloticus range between 0.65 and $2.74 \mathrm{mg} / \mathrm{kg}$ (ww). Ni concentration $(2.74 \mathrm{mg} / \mathrm{kg})$ in farm B was consistent with that found in $[43,56]$, which determined $\mathrm{Ni}$ levels in Tilapia zillii $(2.760 \mathrm{mg} / \mathrm{kg})$ and Oreochromis niloticus $(2.70 \mathrm{mg} / \mathrm{kg})$ from illegal fish farms near the Sabal Drainage Canal and fish from one of the farm ponds in Malaysia, respectively. Nickel concentrations in Taiwanese tilapia fish species [47] ranged between 0.27 and $2.28 \mathrm{mg} / \mathrm{kg}$ dry weight and 2.7 and $3.2 \mathrm{mg} /$ $\mathrm{kg}(\mathrm{ww})$ in O. niloticus, native to Malaysia [47]. The range of average Ni levels observed in muscle tissues for this study was consistent with that of previous researches, though it was higher than the range $0.46-0.58 \mathrm{mg} / \mathrm{kg}$ (ww) reported by [32] in fish species from Burullus Lake in Egypt and $0.24 \mathrm{mg} /$ $\mathrm{kg}$ in farmed Grass carp in China's Pearl River Delta [48]. $O$. niloticus from an unauthorised fish farm in the Sabal drainage canal had a Ni content of $4.611 \mathrm{mg} / \mathrm{kg}$, which was higher than our findings in all the farms [57]. Increased metal concentrations in drainage water discharged into the Sabal Drainage Canal could explain the higher Ni value in the illegally farmed $O$. niloticus muscles than those examined in this study. The Sabal Drainage Canal water is contaminated by fertilisers, agricultural chemicals (pesticides and metals), excess nutrients, and other contaminants from industrial discharge [58]. All tilapia fish samples had $\mathrm{Ni}$ levels greater than the WHO-recommended permissible level of $0.5-0.6 \mathrm{mg} / \mathrm{kg}$ [59]. A high $\mathrm{Ni}$ intake can result in lung and nasal cavity cancer. Ni poisoning symptoms include skin rashes, chest pain, vomiting, nausea, headache, dizziness, diarrhoea, coughing, and body weakness. Prolonged exposure to $\mathrm{Ni}$ vapour can enlarge the brain, liver deterioration, eye discomfort, and a variety of cancers [60].

Arsenic has been classified as a human carcinogen by the International Agency for Research on Cancer [61]. Arsenic is found in both organic and inorganic components in nature. Arsenic in its inorganic form is much more toxic than arsenic in its organic form. Arsenic poisoning can result in bladder, lung, kidney, and skin cancers [44]. Arsenic in the wild fish was most likely derived from natural geological sources as well as pollution caused by industrial activities prevailing in the study area. Arsenic level in wild tilapia (control samples) was $0.23 \mathrm{mg} / \mathrm{kg}(\mathrm{ww})$, below the tolerable limit of $1 \mathrm{mg} / \mathrm{kg}$ proposed by FAO/WHO. The current study's reported level was higher than $0.096 \mathrm{mg} / \mathrm{kg}$ reported by [62] in cultured cyprinid fish species from Northeast China, $0.023 \mathrm{mg} / \mathrm{kg}$ in Bangladeshi fish [44], $0.002 \mathrm{mg} / \mathrm{kg}$ in Taiwanese tilapia [47], and $0.04 \mathrm{mg} / \mathrm{kg}$ in Pearl River Delta Grass [48]. However, the study As level was less than the average value of $0.332 \mathrm{mg} / \mathrm{kg}$ determined in Bangladesh by [63].

When the values from this investigation were compared to those of other local investigations, the values from this study were higher than those in $[41,64]$, except $\mathrm{Zn}$ in River Densu, which was approximately 14 times greater than the values from this study. Ansah et al. [65] determined that the levels of heavy metals in the Weija reservoir were significantly higher than those in cage tilapia from the Volta Basin.

\subsection{Heavy Metals Carcinogenic and Noncarcinogenic Risk} Assessment. The average daily intake of $\mathrm{Cr}, \mathrm{Mn}, \mathrm{Zn}, \mathrm{Ni}$, and $\mathrm{Fe}$ in children and adults who consumed tilapia from the Volta Basin's various cage aquaculture facilities is shown in Table 5. The EDI for heavy metals in fish was significantly less than the Rfd set by the USEPA (2012). For the metals examined, farms $\mathrm{B}$ and $\mathrm{C}$ had the highest Fe values in the 
TABLE 4: Pearson's correlation for heavy metal concentrations in fish and fish feed.

\begin{tabular}{lcccrr}
\hline Metals & $\mathrm{Zn}$ & $\mathrm{Fe}$ & $\mathrm{Mn}$ & $\mathrm{Ni}$ & $\mathrm{Cr}$ \\
\hline $\mathrm{Zn}$ & 0.321 & 0.215 & 0.411 & 0.310 & 0.472 \\
$\mathrm{Fe}$ & 0.215 & $0.958^{* *}$ & $0.852^{* *}$ & 0.222 & 0.311 \\
$\mathrm{Mn}$ & 0.411 & $0.852^{* *}$ & $0.745^{* *}$ & 0.267 & 0.363 \\
$\mathrm{Ni}$ & 0.310 & 0.472 & 0.222 & 0.136 & 0.136 \\
$\mathrm{Cr}$ & 0.247 & 0.311 & 0.363 & 0.481 \\
\hline
\end{tabular}

**Correlation is significant at $p<0.01$ level (two-tailed).

TABle 5: Estimates of average daily dose ( $\mathrm{mg} / \mathrm{kg} /$ day) of heavy metals in tilapia for children and adults for noncarcinogenic risk.

\begin{tabular}{lccccccc}
\hline & \multicolumn{2}{c}{ Fish farm A } & \multicolumn{2}{c}{ Fish farm B } & \multicolumn{2}{c}{ Fish farm C } & \multicolumn{2}{c}{ Control } \\
Metal & Children & Adults & Children & Adults & Children & Adults & Children \\
\hline Zn & $2.76 E-05$ & $2.96 E-06$ & $2.84 E-05$ & $3.05 E-06$ & $2.43 E-05$ & $2.60 E-06$ & $1.29 E-05$ \\
$\mathrm{Fe}$ & $7.72 E-09$ & $5.33 E-05$ & $6.68 E-04$ & $7.17 E-05$ & $5.27 E-04$ & $5.66 E-05$ & $1.48 E-04$ \\
$\mathrm{Mn}$ & $4.55 E-05$ & $4.88 E-06$ & $2.34 E-05$ & $2.52 E-06$ & $3.28 E-05$ & $3.52 E-06$ & $1.03 E-05$ \\
$\mathrm{Ni}$ & $2.16 E-05$ & $2.32 E-06$ & $3.65 E-05$ & $3.92 E-06$ & $2.67 E-05$ & $2.86 E-06$ & $8.67 E-06$ \\
$\mathrm{Cr}$ & $4.13 E-06$ & $4.43 E-07$ & - & - & $4.39 E-06$ & $4.72 E-07$ & $1.10 E-06$ \\
$\mathrm{As}$ & - & - & - & - & - & - & -06 \\
\hline
\end{tabular}

TABLE 6: Noncarcinogenic HQ of heavy metals in cage tilapia for children and adults.

\begin{tabular}{|c|c|c|c|c|c|c|c|c|}
\hline \multirow[b]{2}{*}{ Metal } & \multicolumn{2}{|c|}{ Fish farm A } & \multicolumn{2}{|c|}{ Fish farm B } & \multicolumn{2}{|c|}{ Fish farm C } & \multicolumn{2}{|c|}{ Control } \\
\hline & Children & Adults & Children & Adults & Children & Adults & Children & Adults \\
\hline $\mathrm{Zn}$ & $9.20 E-05$ & $9.87 E-06$ & $9.47 E-05$ & $1.02 E-05$ & $8.10 E-05$ & $8.67 E-06$ & $4.30 E-05$ & $4.63 E-06$ \\
\hline $\mathrm{Fe}$ & $2.14 E-08$ & $1.48 E-04$ & $1.86 E-03$ & $1.99 E-04$ & $1.46 E-03$ & $1.57 E-04$ & $4.11 E-04$ & $4.39 E-05$ \\
\hline $\mathrm{Mn}$ & $3.25 E-03$ & $3.49 E-04$ & $1.67 E-03$ & $1.80 E-04$ & $2.34 E-03$ & $2.51 E-04$ & $7.36 E-04$ & $7.86 E-05$ \\
\hline $\mathrm{Ni}$ & $1.08 E-04$ & $1.16 E-05$ & $1.83 E-04$ & $1.96 E-05$ & $1.34 E-04$ & $1.43 E-05$ & $4.34 E-05$ & $4.65 E-06$ \\
\hline $\mathrm{Cr}$ & $1.38 E-03$ & $1.48 E-04$ & - & - & $1.47 E-03$ & $1.58 E-04$ & $4.43 E-04$ & $4.77 E-05$ \\
\hline As & - & - & - & - & - & - & $1.02 E-02$ & $1.10 E-03$ \\
\hline HI & $4.83 E-03$ & $6.66 E-04$ & $3.81 E-03$ & $4.08 E-04$ & $5.48 E-03$ & $5.88 E-04$ & $2.04 E-02$ & $1.09 E-03$ \\
\hline
\end{tabular}

TABLE 7: EDI of heavy metals in tilapia for children and adults for carcinogenic risk.

\begin{tabular}{|c|c|c|c|c|c|c|c|c|}
\hline \multirow[b]{2}{*}{ Metal } & \multicolumn{2}{|c|}{ Fish farm A } & \multicolumn{2}{|c|}{ Fish farm B } & \multicolumn{2}{|c|}{ Fish farm C } & \multicolumn{2}{|c|}{ Control } \\
\hline & Children & Adults & Children & Adults & Children & Adults & Children & Adults \\
\hline $\mathrm{Zn}$ & $2.36 E-06$ & $1.26 E-06$ & $2.43 E-06$ & $1.30 E-06$ & $2.07 E-06$ & $1.11 E-06$ & $1.11 E-06$ & $5.76 E-07$ \\
\hline $\mathrm{Fe}$ & $4.25 E-05$ & $2.28 E-05$ & $5.71 E-05$ & $3.06 E-05$ & $4.51 E-05$ & $2.42 E-05$ & $1.27 E-05$ & $6.60 E-06$ \\
\hline $\mathrm{Mn}$ & $3.89 E-06$ & $2.08 E-06$ & $2.01 E-06$ & $1.08 E-06$ & $2.80 E-06$ & $1.50 E-06$ & $8.80 E-07$ & $4.59 E-07$ \\
\hline $\mathrm{Ni}$ & $1.85 E-06$ & $9.90 E-07$ & $3.12 E-06$ & $1.67 E-06$ & $2.28 E-06$ & $1.22 E-06$ & $7.43 E-07$ & $3.87 E-07$ \\
\hline $\mathrm{Cr}$ & $3.53 E-07$ & $1.89 E-07$ & - & - & $3.76 E-07$ & $2.02 E-07$ & $1.14 E-07$ & $5.96 E-08$ \\
\hline As & - & - & - & - & - & - & $2.63 E-07$ & $1.37 E-07$ \\
\hline
\end{tabular}

TABLe 8: Cancer risk estimations of heavy metals in cage tilapia for children and adults.

\begin{tabular}{|c|c|c|c|c|c|c|c|c|}
\hline \multirow[b]{2}{*}{ Metal } & \multicolumn{2}{|c|}{ Fish farm A } & \multicolumn{2}{|c|}{ Fish farm B } & \multicolumn{2}{|c|}{ Fish farm $C$} & \multicolumn{2}{|c|}{ Control } \\
\hline & Children & Adults & Children & Adults & Children & Adults & Children & Adults \\
\hline $\mathrm{Cr}$ & $1.77 E-07$ & $9.45 E-08$ & - & - & $1.88 E-07$ & $1.01 E-07$ & $5.70 E-08$ & $2.98 E-08$ \\
\hline $\mathrm{Ni}$ & $5.55 E-08$ & $2.97 E-06$ & $9.36 E-06$ & $5.01 E-06$ & $6.84 E-06$ & $3.66 E-06$ & $6.76 E-07$ & $3.52 E-07$ \\
\hline As & - & - & - & - & - & - & $3.95 E-07$ & $2.06 E-07$ \\
\hline $\mathrm{HI}$ & $2.33 E-07$ & $3.06 E-06$ & $9.36 E-06$ & $5.01 E-06$ & $7.03 E-06$ & $3.76 E-06$ & $6.77 E-07$ & $3.54 E-06$ \\
\hline
\end{tabular}

entire EDI. Although the Fe and Mn contents of O. niloticus muscular tissue tested were above their respective $\mathrm{WHO} /$ WPCL/USEPA thresholds, their calculated EDI values were below the Rfd levels, indicating that these metals pose no risk to humans. However, because heavy metals can accumulate to lethal levels in fish, metal contamination in cage farms 
must be monitored regularly. This can assist in ensuring food safety and identifying any potential health risks associated with eating fish from cage farms.

The hazard quotients (HQ) of metals ingested through fish in the Volta Basin are shown in Table 6. In all of the samples examined, the HQ results for heavy metals in fish ingested by adults and children were consistently less than one. As a result, eating fish farmed in cage aquaculture facilities poses no noncarcinogenic threat to the general public's health. It is also critical to consider the additive effect of pollutants on the population regarding noncarcinogenic risks when assessing the potential consequences for people. The hazard indices of the various metals investigated in this work were less than one for all fish from fish farms analysed and controls. This means that consuming heavy metals from any fish studied poses no significant noncarcinogenic risk to humans.

In Table 7, the computed EDI for carcinogenic risk has been presented. The cancer risk was evaluated using the appropriate carcinogenicity factors for each metal, and the results were reported (see Table 8) based on the carcinogenic risk of the observed EDI. The USEPA issued cancer risk regulations ranging from $1.0 \times 10^{-6}$ to $1.0 \times 10^{-4}$ (USEPA, 2012). The study findings revealed that the estimated cancer risk for $\mathrm{Cr}$, As, and $\mathrm{Ni}$ resulting from consumption of the examined $O$. niloticus from cage aquaculture facilities and the wild was within the USEPA limits. According to the findings of this study, the overall cancer risk of the metals in the fish studied has no impact on the cancer risk for both children and adults who consume fish from the caged farms in the Volta Basin.

\section{Conclusions}

The results indicate that $\mathrm{Zn}, \mathrm{Cr}$, As, $\mathrm{Mn}, \mathrm{Ni}$, and Fe were detected in variable concentrations in all samples, with the level of accumulation varying among tilapia fish from different farms. Except for $\mathrm{Ni}, \mathrm{Mn}$, and $\mathrm{Fe}$, which exceeded permissible levels in fish tissues for human consumption, all other metals in the Oreochromis niloticus muscles were below the USEPA/WHO MRL, implying that fish from the fish farm could potentially cause $\mathrm{Ni}-$, $\mathrm{Fe}-$, and $\mathrm{Mn}$-related health problems over time. According to existing consumption trends, the researchers concluded that the metals of concern provide a negligible noncarcinogenic risk to persons who consume caged tilapia. The cumulative effects of all metals have a hazard index of less than one, effectively eliminating any significant health risk. Furthermore, TCR estimations imply a negligible carcinogenic risk from As, Cr, and $\mathrm{Ni}$ if the tested cultured fish are ingested at their current rate.

\section{Data Availability}

The datasets generated during the current study are not publicly available due to the University policy on data restriction until $\mathrm{PhD}$ thesis is wholly examined. However, data are available from the corresponding author upon reasonable request.

\section{Conflicts of Interest}

The authors declare that they have no conflicts of interest.

\section{Acknowledgments}

The authors are grateful to Dr. Paul Osei-Fosu, Dr. Samuel Lowor, and Dr. Samuel Afful of Ghana Standard Authority (GSA), Cocoa Research Institute of Ghana (CRIG), and the Ghana Atomic Energy Commission (GAEC), respectively, for allowing them access to their laboratories from the extractions stage to the final analyses.

\section{References}

[1] M. P. Kuton, I. O. Ayanda, I. A. Uzoalu, D. I. Akhiromen, A. George, and B. Akinsanya, "Studies on heavy metals and fish health indicators in Malapterurus electricus from Lekki Lagoon, Lagos, Nigeria," Veterinary and Animal Science, vol. 12, p. 100169, 2021.

[2] S. Rajeshkumar and X. Li, "Bioaccumulation of heavy metals in fish species from the meiliang Bay, taihu lake, China," Toxicology reports, vol. 5, pp. 288-295, 2018.

[3] P. M. Kris-Etherton, W. S. Harris, and L. J. Appel, "Fish consumption, fish oil, omega-3 fatty acids, and cardiovascular disease," Circulation, vol. 106, no. 21, pp. 2747-2757, 2002.

[4] S. Zhu, Z. Zhang, and D. Žagar, "Mercury transport and fate models in aquatic systems: a review and synthesis," The Science of the Total Environment, vol. 639, pp. 538-549, 2018.

[5] F. J. Meijide, R. H. Da Cuña, J. P. Prieto, L. S. Dorelle, P. A. Babay, and F. L. Lo Nostro, "Effects of waterborne exposure to the antidepressant fluoxetine on swimming, shoaling and anxiety behaviours of the mosquitofish Gambusia holbrooki," Ecotoxicology and Environmental Safety, vol. 163, pp. 646-655, 2018.

[6] Y. Zhang, X. Lu, N. Wang et al., "Heavy metals in aquatic organisms of different trophic levels and their potential human health risk in Bohai Bay, China," Environmental Science and Pollution Research, vol. 23, no. 17, pp. 17801-17810, 2016.

[7] A. Annabi, K. Said, and I. Messaoudi, "Cadmium: bioaccumulation, histopathology and detoxifying mechanisms in fish," American Journal of Research Communication, vol. 1, no. 4, p. 62, 2013.

[8] E. Georgieva, I. Velcheva, V. Yancheva, and S. Stoyanova, "Trace metal effects on gill epithelium of common carp, Cyprinus carpio L.(Cyprinidae)," Acta Zoologica Bulgarica, vol. 66, no. 2, pp. 277-282, 2014.

[9] D. K. DeForest, K. V. Brix, and W. J. Adams, "Assessing metal bioaccumulation in aquatic environments: the inverse relationship between bioaccumulation factors, trophic transfer factors and exposure concentration," Aquatic Toxicology, vol. 84, no. 2, pp. 236-246, 2007.

[10] M. K. Ahmed, M. A. Baki, G. K. Kundu, M. S. Islam, M. M. Islam, and M. M. Hossain, "Human health risks from heavy metals in fish of Buriganga river, Bangladesh," SpringerPlus, vol. 5, no. 1, pp. 1-2, 2016.

[11] E. B. Mwakalapa, C. K. Simukoko, A. J. Mmochi et al., "Heavy metals in farmed and wild milkfish (Chanos chanos) and wild mullet (Mugil cephalus) along the coasts of Tanzania and associated health risk for humans and fish," Chemosphere, vol. 224, pp. 176-186, 2019.

[12] A. Singh, R. K. Sharma, M. Agrawal, and F. M. Marshall, "Risk assessment of heavy metal toxicity through contaminated 
vegetables from waste water irrigated area of Varanasi, India," Tropical Ecology, vol. 51, no. 2, pp. 375-387, 2010.

[13] A. Sapkota, A. R. Sapkota, M. Kucharski et al., "Aquaculture practices and potential human health risks: current knowledge and future priorities," Environment International, vol. 34, no. 8, pp. 1215-1226, 2008.

[14] J. Larsen and M. Roney, Farmed Fish Production Overtakes Beef, Earth Policy Institute, Washington, NJ, USA, 2013.

[15] E. Amenyogbe, G. Chen, Z. Wang et al., "A review of Ghana's aquaculture industry," J Aquac Res Development, vol. 9, no. 545 , p. 2, 2018.

[16] J. Asiama, I. Abdulai, S. Dotse, and E. Addison, The Fishing Subsector and Ghanas Economy, Bank of Ghana, Accra, Ghanga, 2008.

[17] M. Kim, S. Kim, S. J. Yun, J.-W. Kwon, and S.-W. Son, "Evaluation of PCDD/Fs characterization in animal feed and feed additives," Chemosphere, vol. 69, no. 3, pp. 381-386, 2007.

[18] B. M. Tiimub, E. Dartey, and C. K. Avornyotse, "Determination of selected heavy metals contamination in water from downstream of the Volta Lake at Manya Krobo district in eastern region of Ghana," International Research Journal of Public and Environmental Health, vol. 2, no. 11, pp. 167-173, 2015.

[19] A. Y. Karikari, R. Asmah, W. W. Anku et al., "Heavy metal concentrations and sediment quality of a cage farm on Lake Volta, Ghana," Aquaculture Research, vol. 51, no. 5, pp. 2041-2051, 2020.

[20] R. Asmah, A. Y. Karikari, E. K. Abban, J. K. Ofori, and L. K. Awity, "Cage fish farming in the Volta Lake and the Lower Volta: practices and potential impacts on water quality," Ghana Journal of Science, vol. 54, pp. 33-47, 2014.

[21] E. T. D. Mensah and F. K. Attipoe, "Growth parameters and economics of tilapia cage culture using two commercial fish diets," International Journal of Development and Sustainability, vol. 2, no. 2, pp. 825-837, 2013.

[22] J. K. Ofori, E. K. Abban, A. Y. Karikari, and R. E. Brummett, "Production parameters and economics of small-scale tilapia cage aquaculture in the Volta Lake, Ghana," Journal of Applied Aquaculture, vol. 22, no. 4, pp. 337-351, 2010.

[23] C. Kamunda, M. Mathuthu, and M. Madhuku, "Potential human risk of dissolved heavy metals in gold mine waters of Gauteng Province, South Africa," Journal of Toxicology and Environmental Health Sciences, vol. 10, no. 6, pp. 56-63, 2019.

[24] USEPA, Edition of the Drinking Water Standards and Health Advisories, U.S. Environmental Protection Agency, Washington, NJ, USA, 2012.

[25] G. Darko, S. Boakye, O. Akoto, M. Rammika, and O. Gyamf, "Distribution and potential risks of heavy metals in fish," Water and Sediment ESAIJ, vol. 11, no. 3, pp. 74-82, 2015.

[26] F. Gbogbo, A. Arthur-Yartel, J. A. Bondzie et al., "Risk of heavy metal ingestion from the consumption of two commercially valuable species of fish from the fresh and coastal waters of Ghana," Plos one, vol. 13, no. 3, p. e0194682, 2018.

[27] E. Gyimah, O. Akoto, and C. Nimako, "Health risk assessment of heavy metals contamination in edible fish species from the Barekese Reservoir in Kumasi, Ghana," Toxicology and Applied Pharmacology Insights, vol. 2, no. 1, pp. 1-7, 2018.

[28] U. B. Onyedikachi, D. C. Belonwu, and M. O. Wegwu, "Human health risk assessment of heavy metals in soils and commonly consumed food crops from quarry sites located at Isiagwu, Ebonyi State," Ovidius University Annals of Chemistry, vol. 29, no. 1, pp. 8-24, 2018.

[29] F. Zeng, W. Wei, M. Li, R. Huang, F. Yang, and Y. Duan, "Heavy metal contamination in rice-producing soils of Hunan province, China and potential health risks," International Journal of Environmental Research and Public Health, vol. 12, no. 12, pp. 15584-15593, 2015.

[30] E. J. Mitchell, S. H. Frisbie, S. Roudeau, A. Carmona, and R. Ortega, "Estimating daily intakes of manganese due to breast milk, infant formulas, or young child nutritional beverages in the United States and France: comparison to sufficiency and toxicity thresholds," Journal of Trace Elements in Medicine \& Biology, vol. 62, p. 126607, 2020.

[31] L. I. Ezemonye, P. O. Adebayo, A. A. Enuneku, I. Tongo, and E. Ogbomida, "Potential health risk consequences of heavy metal concentrations in surface water, shrimp (Macrobrachium macrobrachion) and fish (Brycinus longipinnis) from Benin River, Nigeria," Toxicology Reports, vol. 6, pp. 1-9, 2019.

[32] O. A. El-Batrawy, M. I. El-Gammal, L. I. Mohamadein, D. H. Darwish, and K. M. El-Moselhy, "Impact assessment of some heavy metals on tilapia fish, Oreochromis niloticus, in Burullus Lake, Egypt," The Journal of Basic and Applied Zoology, vol. 79, no. 1, pp. 1-2, 2018.

[33] A. Türkmen, M. Türkmen, Y. Tepe, and I. Akyurt, "Heavy metals in three commercially valuable fish species from Iskenderun Bay, northern East Mediterranean Sea, Turkey," Food Chemistry, vol. 91, no. 1, pp. 167-172, 2005.

[34] W. Zhong, Y. Zhang, Z. Wu et al., "Health risk assessment of heavy metals in freshwater fish in the central and eastern North China," Ecotoxicology and Environmental Safety, vol. 157, pp. 343-349, 2018.

[35] C. Korkmaz, Ö. Ay, Y. Ersoysal, M. A. Köroğlu, and C. Erdem, "Heavy metal levels in muscle tissues of some fish species caught from north-east Mediterranean: evaluation of their effects on human health," Journal of Food Composition and Analysis, vol. 81, pp. 1-9, 2019.

[36] M. Ali and A. Abdel-Satar, "Studies of some heavy metals in water, sediment, fish and fish diets in some fish farms in ElFayoum province," Egyptian Journal of Aquatic Research, vol. 31, no. 2, pp. 261-273, 2005.

[37] E. Effah, D. W. Aheto, E. Acheampong, S. K. Tulashie, and J. Adotey, "Human health risk assessment from heavy metals in three dominant fish species of the Ankobra river, Ghana," Toxicology Reports, vol. 8, pp. 1081-1086, 2021.

[38] B. Wu, G. Wang, J. Wu, Q. Fu, and C. Liu, "Sources of heavy metals in surface sediments and an ecological risk assessment from two adjacent plateau reservoirs," PLoS One, vol. 9, no. 7, p. e102101, 2014.

[39] A. Ateş, M. Türkmen, and Y. Tepe, "Assessment of heavy metals in fourteen marine fish species of four turkish seas," Indian Journal of Geo-Marine Sciences, vol. 44, pp. 49-55, 2015.

[40] B. Ersoy and M. Çelik, "The essential and toxic elements in tissues of six commercial demersal fish from Eastern Mediterranean Sea," Food and Chemical Toxicology, vol. 48, no. 5, pp. 1377-1382, 2010.

[41] A. K. Anim, E. K. Ahialey, G. O. Duodu, M. Ackah, and N. O. Bentil, "Accumulation profile of heavy metals in fish samples from Nsawam, along the Densu river, Ghana," Research Journal of Environmental and Earth Sciences, vol. 3, no. 1, pp. 56-60, 2011.

[42] M. Mensoor and A. Said, "Determination of heavy metals in freshwater fishes of the Tigris River in Baghdad," Fishes, vol. 3, no. 2, p. 23, 2018 Jun.

[43] A. Taweel, M. Shuhaimi-Othman, and A. K. Ahmad, "Heavy metals concentration in different organs of tilapia fish (Oreochromis niloticus) from selected areas of Bangi, Selangor, 
Malaysia," African Journal of Biotechnology, vol. 10, no. 55, pp. 11562-11566, 2011.

[44] N. S. Resma, A. M. H. Meaze, S. Hossain, M. U. Khandaker, M. Kamal, and N. Deb, "The presence of toxic metals in popular farmed fish species and estimation of health risks through their consumption," Physics Open, vol. 5, p. 100052, 2020.

[45] S. Hasan, L. Rahman, and S. Chowdhury, "Prevalence of chromium in fish feed and commercially cultivated tilapia," SSRN Electronic Journal, 2016.

[46] S. C. Srivastava, P. Verma, A. K. Verma, and A. K. Singh, "Assessment for possible metal contamination and human health risk of Pangasianodon hypophthalmus (Sauvage, 1878) farming, India," Int J Fish Aquat Stud, vol. 1, pp. 176-181, 2014.

[47] Y.-R. Ju, C.-W. Chen, C.-F. Chen, X.-Y. Chuang, and C.-D. Dong, "Assessment of heavy metals in aquaculture fishes collected from southwest coast of Taiwan and human consumption risk," International Biodeterioration \& Biodegradation, vol. 124, pp. 314-325, 2017.

[48] B. Mao, Z. Huang, F. Zeng et al., “Assessment of heavy metal pollution in the water, sediment and fish during a complete breeding cycle in the pond of the Pearl River Delta, China," Journal of Environmental Protection, vol. 11, no. 06, pp. 509-530, 2020.

[49] A. Bakshi and A. K. Panigrahi, "A comprehensive review on chromium induced alterations in fresh water fishes," Toxicology reports, vol. 5, pp. 440-447, 2018.

[50] A. S. S. Ahmed, M. Rahman, S. Sultana, S. M. O. F. Babu, and M. S. I. Sarker, "Bioaccumulation and heavy metal concentration in tissues of some commercial fishes from the Meghna River Estuary in Bangladesh and human health implications," Marine Pollution Bulletin, vol. 145, pp. 436-447, 2019.

[51] H. Alipour, A. Pourkhabbaz, and M. Hassanpour, "Estimation of potential health risks for some metallic elements by consumption of fish," Water Quality, Exposure and Health, vol. 7, no. 2, pp. 179-185, 2015.

[52] I. O. Ayanda, U. I. Ekhator, and O. A. Bello, "Determination of selected heavy metal and analysis of proximate composition in some fish species from Ogun River, Southwestern Nigeria," Heliyon, vol. 5, no. 10, p. e02512, 2019.

[53] World Health Organization, Adverse Health Effects of Heavy Metals in Children, World Health Organization, Geneva, Switzerland, 2011.

[54] M. K. Ahmed, N. Shaheen, M. S. Islam et al., "Dietary intake of trace elements from highly consumed cultured fish (Labeo rohita, Pangasius pangasius and Oreochromis mossambicus) and human health risk implications in Bangladesh," Chemosphere, vol. 128, pp. 284-292, 2015.

[55] A. A. Bawuro, R. B. Voegborlo, and A. A. Adimado, "Bioaccumulation of heavy metals in some tissues of fish in Lake Geriyo, Adamawa State, Nigeria," Journal of Environmental and Public Health, vol. 2018, 2018.

[56] A. A. Alne-na-ei, "The illegal fish farms in the Egyptian Delta: external lesions frequency, liver histopathology and heavy metals concentrations in the muscle tissue. Egypt," Journal on Aquatic Biology and Fisheries, vol. 2, no. 4, pp. 119-144, 1998.

[57] M. M. N. Authman, W. T. Abbas, and A. Y. Gaafar, "Metals concentrations in Nile tilapia Oreochromis niloticus () from illegal fish farm in Al-Minufiya Province, Egypt, and their effects on some tissues structures," Ecotoxicology and Environmental Safety, vol. 84, pp. 163-172, 2012.
[58] E. A. Khallaf, M. Galal, and M. Authman, "The biology of Oreochromis niloticus in a polluted canal," Ecotoxicology, vol. 12, no. 5, pp. 405-416, 2003.

[59] R. Hashim, T. H. Song, N. Z. Muslim, and T. P. Yen, "Determination of heavy metal levels in fishes from the lower reach of the Kelantan River, Kelantan, Malaysia," Tropical Life Sciences Research, vol. 25, no. 2, pp. 21-39, 2014.

[60] M. A. Mannan, M. S. Hossain, M. A.-A. Sarker et al., "Bioaccumulation of toxic heavy metals in fish after feeding with synthetic feed: a potential health risk in Bangladesh," Journal of Nutrition \& Food Sciences, vol. 8, no. 5, p. 1000728, 2018.

[61] IARC I 2012 IARC monographs on the evaluation of carcinogenic risks to humans: arsenic, metals, fibres, and dusts. A Review of Human Carcinogens.

[62] D. Qin, H. Jiang, S. Bai, S. Tang, and Z. Mou, "Determination of 28 trace elements in three farmed cyprinid fish species from Northeast China," Food Control, vol. 50, pp. 1-8, 2015.

[63] A. K. M. A. Ullah, M. A. Maksud, S. R. Khan, L. N. Lutfa, and S. B. Quraishi, "Dietary intake of heavy metals from eight highly consumed species of cultured fish and possible human health risk implications in Bangladesh," Toxicology Reports, vol. 4, pp. 574-579, 2017.

[64] M. Anim-Gyampo, M. Kumi, and M. S. Zango, "Heavy metals concentrations in some selected fish species in Tono Irrigation Reservoir in Navrongo, Ghana," Journal of Environment and Earth Science, vol. 3, no. 1, pp. 109-119, 2013.

[65] E. Ansah, D. Nukpezah, and J. N. Hogarh, "Levels and distribution of heavy metals in Weija reservoir, Accra, Ghana," West African Journal of Applied Ecology, vol. 26, no. 1, pp. 74-88, 2018. 